\title{
Mycorrhizal and septate endophytic fungal associations in gymnosperms of southern India
}

Kandhasamy Nagaraj, Perumalsamy Priyadharsini \& Thangavelu Muthukumar

Root and Soil Biology Laboratory, Department of Botany, Bharathiar University, Coimbatore - 641046, Tamilnadu, India

Correspondence

T. Muthukumar

E-mail: tmkum@yahoo.com

Received: 14 July 2014

Accepted: 17 April 2015

Published on-line: 1 June 2015

\section{Resumen}

Asociaciones fúngicas de micorrizas y endófitos septados en gimnospermas del sur de la India

Sólo un pequeño porcentaje de las asociaciones fúngicas de plantas que crecen en ambientes naturales han sido examinadas. Por ese motivo, nosotros examinamos asociaciones fúngicas de 15 gimnospermas del sur de la India. Todas estas plantas fueron colonizadas por micorrizas arbusculares y 7 de ellas fueron co-colonizadas por hongos endófitos septados Se cita por primera vez la presencia de asociaciones micorrizas arbusculares y endófitos septados en 10 y 5 gimnospermas, respectivamente. La colonización por micorrizas arbusculares caracterizadas por morfologías Paris e Intermedio se citan por primera vez para 11 especies de plantas. Se han asociado 6 esporas de micorrizas arbusculares, de los géneros Glomus, Claroideoglomus, Funneliformis y Scutellospora, a las rizosferas de gimnospermas.

Palabras clave: Micorriza arbuscular, Ectomicorriza, Glomus, Hongos endófitos septados.

\begin{abstract}
Only a small percentage of plants growing in natural habitats are examined for their endophytic fungal associations. Therefore, we examined 15 gymnosperms growing in southern India for their endophytic fungal associations. All gymnosperms were colonized with arbuscular mycorrhizal fungi, of which seven had co-colonization by septate endophytic fungi. Presence of arbuscular mycorrhizal and septate endophytic fungal association has been reported for the first time in ten and five gymnosperms respectively. Arbuscular mycorrhizal colonization characterized by Paris- and intermediate-type morphologies have been reported for the first time in 11 plant species. Six AM fungal spore morphotypes belonging to Glomus, Claroideoglomus, Funneliformis and Scutellospora were associated with the rhizospheres of the gymnosperms.
\end{abstract}

Key words: Arbuscular mycorrhiza, Ectomycorrhiza, Glomus, Gymnosperms, Septate endophytic fungi. 


\section{Introduction}

Gymnosperms, the naked seeded vascular plants are a major component of the temperate forests. There are more than 1000 extant species of gymnosperms belonging to 88 genera and 14 families distributed in various parts of the world (The Plant List 2015). In India, the gymnosperm diversity encompasses 101 species, four varieties and one form in 33 genera (Srivastava 2006). Fossil evidence do suggest the presence of arbuscular mycorrhizal (AM)-like association characterized by arbuscules and vesicles in gymnosperms from the Carboniferous period, and this type of mycorrhiza continue to exist in a majority of the extant gymnosperm tree species (Wang \& Qiu 2006). A summary of the mycorrhizal status of gymnosperms by Wang \& Qiu (2006) indicated that members of gymnosperm families like Cycadaceae, Zamiaceae, Ephedraceae, Welwitschiaceae, Podocarpaceae, Taxoidaceae and Taxaceae are exclusively AM, whereas those belonging to Gnetaceae and Pinaceae are predominantly ectomycorrhizal (EM). In EM association, the fungi typically form a sheath on the root surface called as mantle and a Hartig net consisting of the intercellular fungal hyphae within host roots (Horton et al. 1998, Wagg et al. 2008, Brundrett 2009). Ectomycorrhizal association has been reported to exist in family Pinaceae since approximately 130 MYA (Smith \& Read 2008). In addition, taxa in Araucariaceae and Cupressaceae are capable of associating with both EM and AM fungi.

Mycorrhizal fungi affect growth and development of gymnosperms both under green house and field conditions. Ouahmane et al. (2007) showed that seedlings of Cupressus dupreziana var. atlantica (Gaussen) Silba (=Cupressus atlantica Gaussen) inoculated with native AM fungi had a better growth both under greenhouse and field conditions. The influence of mycorrhizal fungi on plant growth has often been attributed to the enhanced $\mathrm{N}$ and $\mathrm{P}$ nutrition of the host plant through mineralization of soil organic matter and/or extending the absorptive surface available for plant's uptake (Smith \& Read 2008). Inspite of their importance, only 82 gymnosperms have been examined for their mycorrhizal status (Wang \& Qiu 2006).

During the past decade, considerable development has been made to improve the outplant per- formance of forest tree species on various reafforestation sites by using specific mycorrhizal fungal strains (Caravaca et al. 2003). The identification of an efficient mycorrhizal fungus is therefore considered as a prerequisite for inoculation programs as the efficiency of mycorrhizal inoculation on the plant growth often depends on the fungal species involved (Smith \& Read 2008). To achieve this, understanding of the mycorrhizal status and mycorrhizal dependence of plant species is often necessary. For example, a plant taxa may be EM in certain regions and AM in other regions (Diagne et al. 2013).

The diversity of mycorrhizal fungal associated with gymnosperms also tends to be influenced by several factors. For instance, an assessment on the mycorrhizal status of Araucaria angustifolia (Bertol.) Kuntze suggested that the AM fungal diversity and richness, were usually higher in native areas compared with the reforested area (Moreira et al. 2003, 2006). Unlike EM fungi, AM fungi often colonize a wide range of plant species due to their low host specificity (Allen et al. 1995). However, in certain cases, AM fungi do exhibit a certain degree of host preference in natural ecosystems as certain fungal taxa proliferate specifically with certain plant species (Bever et al. 2001, Helgason et al. 2002).

In addition to $\mathrm{AM}$ and $\mathrm{EM}$ fungi, certain ascomycetes fungi often termed as dark septate or septate endophytic (SE) fungi also colonize living plant root tissues both intracellularly and intercellularly and exhibit a wide range of interactions (Jumpponen \& Trappe 1998). In certain regions, SE fungi are most commonly found in fine roots of trees and shrubs, particularly in conifers exhibiting little host or habitat specificity (Ahlich \& Sieber 1996). In addition, SE fungi can also occur in harsh climatic conditions (Jumpponen \& Trappe 1998, Addy et al. 2005). The SE fungal association has been reported in about 600 plant species of 320 genera in 114 families, including several gymnosperms that are mycorrhizal (Jumpponen \& Trappe 1998).

Co-occurrence of AM and SE fungi has been reported in gymnospermous families like Cupressaceae, Cycadaceae, Pinaceae and Podocarpaceae (Jumpponen \& Trappe 1998, Muthukumar \& Udaiyan 2002). Wagg et al. (2008) reported the co-occurrence of AM and SE fungi in the roots of four members of Pinaceae [Pinus banksiana 
Lamb., Pinus strobus L., Pinus contorta Douglas ex Loudon, and Picea glauca x Picea engelmannii (hybrid spruce)] from a disturbed forest area in central Canada. In India, although ecto- and endomycorrhizal associations have been reported for limited number of gymnosperms (Smith \& Smith 1997), such reports are scarce for gymosperms of southern India. The same holds true for SE fungal association for south Indian gymnosperms. Previously, Muthukumar \& Udaiyan (2002) investigated the AM status of three species of cycads from southern India and observed inter, intracellular hyphae, arbuscules and vesicles in the cortex resembling typical Arum-type AM morphology. In addition, these authors also reported moderate levels of AM fungal colonization in cycads and an inverse relationship of root hair density and root hair length to AM fungal colonization (Muthukumar \& Udaiyan 2002). The present study, therefore, was carried out with the following objectives: i) to determine the mycorrhizal and SE status of South Indian gymnosperms, and ii) to assess if any relationship exists between the different fungal variables.

\section{Material and Methods}

\section{Study sites}

This study was carried out at Coimbatore (hereafter referred to as site-A) and the Nilgiris (hereafter referred to as site-B) located at $11^{\circ} 16^{\prime \prime} \mathrm{N}$, $76^{\circ} 58^{\prime} \mathrm{E}$ and $11^{\circ} 22^{\prime} \mathrm{N}, 76^{\circ} 45^{\prime} \mathrm{E}$ respectively. The altitude and average annual rainfall are 411 and 2,290 MAMSL, and 674.2 and 1,960 $\mathrm{mm}$ at sites $\mathrm{A}$ and $\mathrm{B}$ respectively. The soil characteristics and the number of plant taxa examined from each site are presented in Table 1.

\section{Sample collection}

We collected root and soil samples of 15 gymnosperms belonging to seven families during January and February 2013 from the two different sites of southern India. Three plants comprising of both seedlings and trees were sampled for each taxa. One species, Pinus roxburghii Sarg. occurred at both the sites (Table 2). The roots were collected carefully and positively identified as belonging to the desired plant in order to avoid the collection of roots from unintended species. Roots were washed gently with tap water and stored in FAA (formalin: glacial acetic acid: $70 \%$ ethyl al- cohol, 5:5:90, v:v:v) until processing. The rhizosphere soil collected from the individual plants was shade dried, packed separately in polythene bags, labelled and stored at $4{ }^{\circ} \mathrm{C}$. One part of this soil samples were used for enumeration as well as the extraction of AM fungal spores. The other part of the soil samples from all the individuals of a site was bulked and used for soil characterization. The plant nomenclature and authorities for gymnosperms are according to http://www.plantsystematics.org/, and http://www.theplantlist.org/.

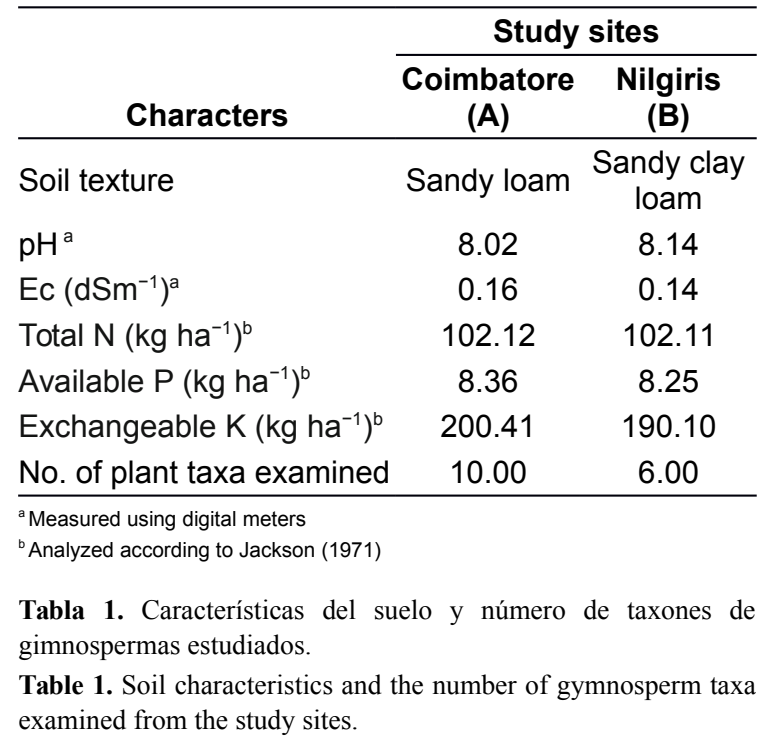

\section{Determination of ectomycorrhizal associa- tion}

The FAA fixed roots were washed in tap water. Assessment of root length with ectomycorrhizal association was made according to Brundrett et al. (1996).

\section{Preparation of roots for AM and SE fungal assessment}

The fixed roots were washed thoroughly free of FAA with tap water, cut into $1-\mathrm{cm}$ long bits, and processed for AM fungal assessment according to Koske \& Gemma (1989). Thirty trypan blue stained root bits were examined with an Olympus BX51 compound microscope (x400) for the presence of AM and SE fungal structures. Five intersection points was observed for each root bit. The percentage of root length colonization by AM and SE fungi was estimated according to the magnified intersection method (McGonigle et al. 1990). The AM morphology type was determined based 


\begin{tabular}{|c|c|c|c|c|c|}
\hline \multirow{2}{*}{ Family / Plant name } & \multirow{2}{*}{ Site } & \multirow{2}{*}{ Mycorrhizal Status } & \multirow{2}{*}{ AM type } & \multicolumn{2}{|c|}{ Previous reports } \\
\hline & & & & Association & AM type \\
\hline \multicolumn{6}{|l|}{ Araucariaceae } \\
\hline Araucaria heterophylla & $A$ & $\mathrm{AM}^{*}, \mathrm{SE}^{*}$ & $P^{*}$ & -- & -- \\
\hline \multicolumn{6}{|l|}{ Cupressaceae } \\
\hline Chamaecyparis obtusa & B & $\mathrm{AM}^{*}, \mathrm{SE}^{*}$ & $\mathrm{P}^{*}$ & -- & -- \\
\hline Cupressus macrocarpa & $\mathrm{B}$ & $\mathrm{AM}^{*}$ & $P^{*}$ & -- & -- \\
\hline Cupressus sempervirens & $A$ & $\mathrm{AM}^{*}, \mathrm{SE}^{*}$ & $\mathrm{P}^{*}$ & -- & -- \\
\hline Cupressus torulosa & B & $\mathrm{AM}^{*}, \mathrm{SE}^{*}$ & $P^{*}$ & -- & -- \\
\hline Platycladus orientalis & $A$ & $\mathrm{AM}^{*}$ & $\mathrm{P}^{*}$ & -- & -- \\
\hline Thuja sp. & $A$ & AM, SE & 1 & -- & -- \\
\hline \multicolumn{6}{|l|}{ Taxodiaceae } \\
\hline Cryptomeria japonica & A & AM & $\mathrm{P}$ & $\mathrm{AM}^{2,5,10}$ & $P$ \\
\hline \multicolumn{6}{|l|}{ Cycadaceae } \\
\hline Cycas circinalis & $A$ & AM,SE & 1 & $\mathrm{AM}^{4,6,7}, \mathrm{SE}^{7}$ & A \\
\hline \multicolumn{6}{|l|}{ Pinaceae } \\
\hline \multirow[t]{2}{*}{ Pinus roxburghii } & $A$ & EM & -- & $\mathrm{EM}^{1,3,4,8,9}$ & -- \\
\hline & $\mathrm{B}$ & $\mathrm{AM}^{*}$ & $I^{*}$ & -- & -- \\
\hline \multicolumn{6}{|l|}{ Podocarpaceae } \\
\hline Podocarpus sp. & A & AM & 1 & -- & -- \\
\hline Podocarpus elongata & B & $\mathrm{AM}^{*}, \mathrm{SE}^{*}$ & $P^{*}$ & -- & -- \\
\hline Podocarpus macrophyllus & $A$ & $\mathrm{AM}$ & $I^{*}$ & $\mathrm{AM}^{4}$ & -- \\
\hline Prumnopitys taxifolia & A & $\mathrm{AM}^{*}$ & $I^{*}$ & -- & -- \\
\hline \multicolumn{6}{|l|}{ Zamiaceae } \\
\hline Zamia furfuracea & A & $\mathrm{AM}^{*}$ & $\mathrm{P}^{*}$ & -- & -- \\
\hline
\end{tabular}

Site: A: Coimbatore; B: Nilgiris

AM type: P, Paris-type; I, Intermediate-type

*First report of AM-type, AM and SE association

1 Bakshi (1957), 2 Gallaud (1905), 3 Ghildiyal et al. (2010), 4 lqbal et al. (1990), 5 Konoe (1957), 6 Muthukumar and Udaiyan (2002), 7 Muthukumar et al. (2006), 8 Rawat et al. (2004), 9 Singer and Singh (1971) \& 10 Yamato and Iwasaki (2002)

Tabla 2. Asociaciones con ectomicorrizas (EM), micorrizas arbusculares (AM) y endófitos septados (SE), y morfología de AM, con referencias anteriores en gimnospermas del sur de la India.

Table 2. Ectomycorrhizal (EM), Arbuscular mycorrhizal (AM), septate endophyte (SE) fungal associations, and AM morphology along with the previous reports in gymnosperms of southern India.

on descriptions of Dickson (2004). Regularly septate, melanized or hyaline hyphae with microsclerotia or moniliform cells characterized SE fungal colonization.

\section{Isolation, enumeration and identification of AM fungal spores}

The AM fungal spores were isolated and enumerated according to Muthukumar \& Udaiyan (2000). Briefly, the soil suspension was prepared by mixing $100 \mathrm{~g}$ of soil to $1 \mathrm{~L}$ of water. The suspension was then decanted through a nested series of sieves $(720$ to $35 \mu \mathrm{m})$ and the sievates were collected over filter papers. The filter papers were spread on a glass plate and examined using a stereomicroscope. All intact spores (non-collapsed spores with cytoplasmic contents and free from parasitic attack) were counted, picked and mounted in polyvinyl alcohol-lactoglycerol with or without Melzer's reagent for identification (Schenck \& Perez 1990). The spores were identified according to the observations of morphology and sub-cellular characters under an Olympus BX51 compound microscope and by comparing with the original descriptions of Schüßlers lab web page (http://www.lrz-muenchen.de/ schuessl er/amphylo/amphlo_species.html) and also by using culture data base established by INVAM (http:/invam.cag.wvu.edu). Frequency of occurrence was calculated using the formula: Frequency $(\%)=[$ No. of soil samples in which a particular spore morphotype was present/Total num- 
ber of soil samples examined] x100 (Beena et al. 2000).

\section{Statistical analysis}

Data of AM and SE fungal colonization was subjected to Analysis of Variance (ANOVA) to assess the significance of variation between plant species. Pearson's correlation was used to assess the relationship between AM and SE fungal colonization. As data on root colonization and spore numbers follow a negative binomial distribution (St. John \& Koske 1988), these data were respectively arcsine and log transformed prior to statistical analysis.

\section{Results}

\section{Ecto- and endo-mycorrhizal association}

All the gymnosperms examined from the two different sites, had AM fungal association and $P i$. roxburghii (Pinaceae) examined from site-A had ectomycorrhizal association. Ectomycorrhizal association in Pi. roxburghii was characterized by the presence of a fungal mantle covering the root surface and a Hartig net. The presence of Hartig net was restricted mainly to the outer cortex region and the hyphae never penetrated the endodermis (Figs. 1a, 1b) and the root length colonization was $43.56 \%$.

The AM fungal colonization was characterized by the presence of an appressorium on the root surface at the point of hyphal penetration, inter or intracellular linear hyphae, intracellular hyphal coils, intra- or inter-cellular vesicles that were terminal or intercalary and arbuscules/arbusculate coils in the root cortex (Figs. 1c-g). Linear hyphae were not observed in nine plant species: Araucaria heterophylla (Salisb.) Franco (Araucariaceae); Chamaecyparis obtusa (Siebold \& Zucc.) Endl. [=Cupressus obtusa (Siebold \& Zucc.) F.Muell.], Cupressus macrocarpa Hartw. ex Gord., Cupressus sempervirens L., Cupressus torulosa D.Don, Platycladus orientalis (L.) Franco $[=$ Biota orientalis (Siebold \& Zucc.) F.Muell.] (Cupressaceae); Cryptomeria japonica (L.f.) D.Don (Taxodiaceae); Podocarpus elongatus (Aiton) L'Herit. ex Persoon (Podocarpaceae); Zamia furfuracea L.f. in Aiton (Zamiaceae). Vesicles were absent in four plant species: Pl. orientalis, Cr. japonica, Pi. roxburghii, Za. furfuracea.
Arbuscular mycorrhizal fungal spores were observed in roots of Ar. heterophylla and Za. furfuracea (Fig. 1j).

\section{Distribution of AM morphological types}

Most of the gymnosperms $(67 \%, 10 / 15)$ had features that were typical of Paris-type AM morphology. Typical Paris-type colonization is characterized by intracellular hyphal coils, arbusculate coils and intracellular vesicles. Six of the gymnosperms, like Thuja sp. L. (Cupressaceae), Cycas circinalis L. (Cycadaceae), Pi. roxburghii, Prumnopitys taxifolia (Banks et Sol. ex D.Don) de Laub. (=Podocarpus taxifolius Kunth), Podocarpus macrophyllus (Thunb.) D.Don, Podocarpus sp. Labill. (Podocarpaceae), had intermediate-type characterized by intercellular hyphae, intracellular arbusculate coils and hyphal coils (Table 2).

\section{Extent of AM fungal colonization}

The extent of AM fungal colonization and root length colonized by AM fungal structures varied significantly among the plant species. The percentage of root length with total colonization (\% RLTC) ranged between $41 \%$ (Ch. obtusa) and $67 \%$ (Pl. orientalis) and significantly varied among plant species $\left(\mathrm{F}_{14,44}=7.75 ; \mathrm{P}<0.01\right)$. The percentage root length with hyphae $(\% \mathrm{RLH})$ ranged between 3\% (Podocarpus sp.) and 14\% (Po. macrophyllus) and significantly varied among plant species $\left(\mathrm{F}_{14,44}=30.30 ; \mathrm{P}<0.01\right)$. Percentage root length with hyphal coils (\% RLHC) and arbusculate coils (\% RLAC) ranged from 8\% (Po. elongata) to $42 \%$ (Po. macrophyllus) and $9 \%$ (Za. furfuracea) to $40 \%$ (Pl. orientalis) and varied significantly among plant species $\left(\mathrm{F}_{14,44}=16.32\right.$; $\left.\mathrm{P}<0.01 ; \mathrm{F}_{14,44}=8.10 ; \mathrm{P}<0.01\right)$. The percentage root length with vesicles (\% RLV) significantly varied among plant species $\left(\mathrm{F}_{14,44}=10.43\right.$; $\mathrm{P}<0.01)$ and ranged from 3\% (Ch. obtusa, Thuja sp.) to $14 \%$ (Cy. circinalis, Podocarpus sp.) (Table 3).

\section{Distribution of AM fungal spores}

Six AM fungal spore morphotypes were distinguished, on the basis of spore morphology from the soils of gymnosperms examined (Fig. 2). These included Glomus aggregatum Schenck \& Smith, Glomus viscosum Nicolson, Claroideoglomus etunicatum (Becker \& Gerd.) Walker \& Schüßler, Funneliformis geosporum (Nicolson \& 


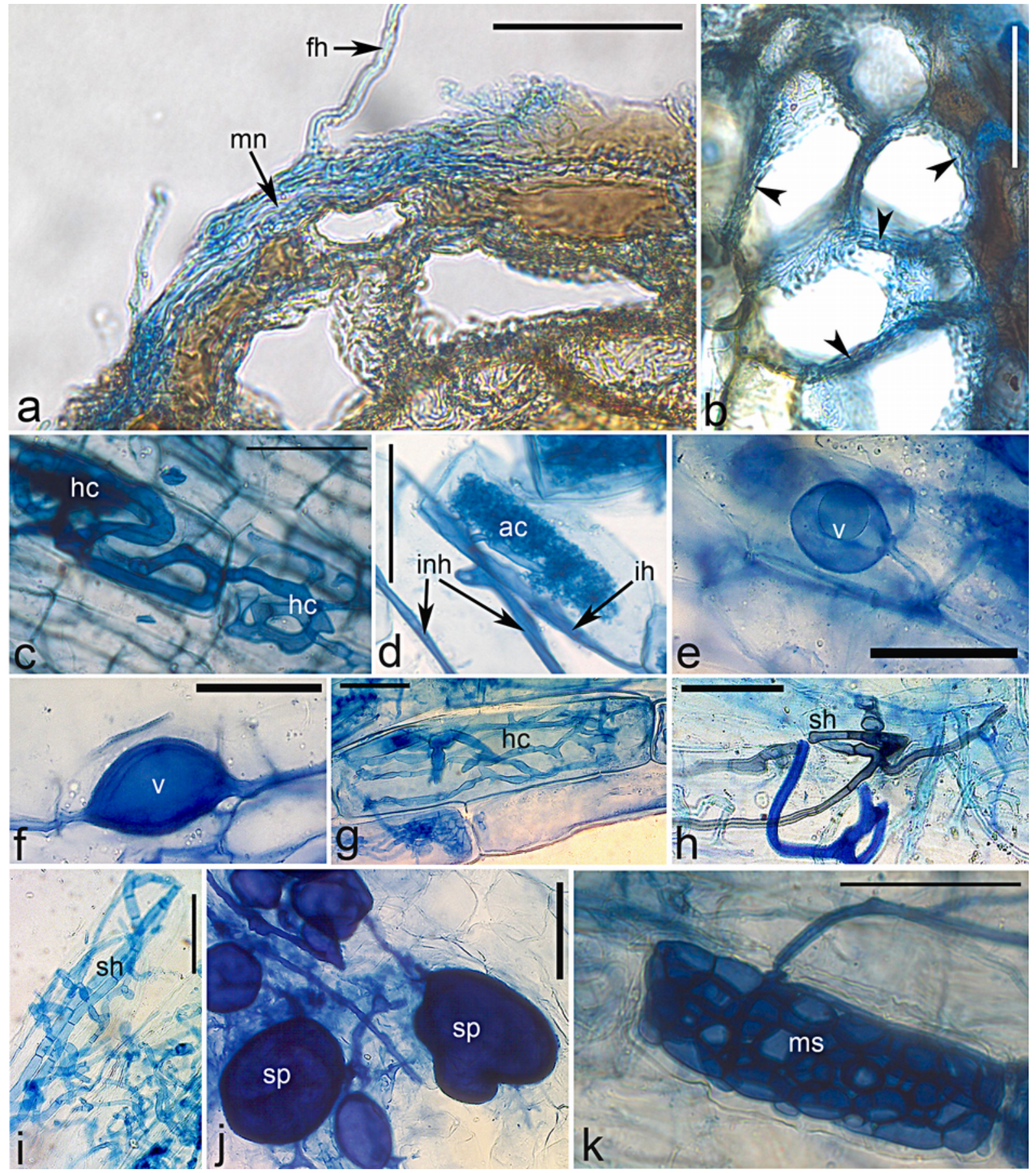

Figura 1. Asociaciones fúngicas de ectomicorrizas, micorrizas arbusculares (AM) y endófitos septados en gimnospermas. a: Sección transversal de Pinus roxburghii mostrando el manto (mn) y la hifa (fh); b: Red de Harting (flechas) en el cortex radicular de Pi. roxburghii; c: Rulo hifal (hc) en Platycladus orientalis; d: Rulo arbuscular (ac), hifas intracelular (ih) y intercelular (inh) en célula cortical de Podocarpus macrophyllus; e: Vesícula intracelular (v) en Cycas circinalis; f: Vesícula intercalar en Cupressus macrocarpa; g: Rulo hifal AM intracelular (hc) en Cryptomeria japonica; h: Hifas septadas (sh) en Cupressus torulosa. i: Hifas septadas (sh) en Cy. circinalis; j: Esporas AM en raíz de Zamia furfuracea; k: Esclerocios en celula cortical de raíz de Thuja sp.. Barra de escala $=50 \mu \mathrm{m}$.

Figure 1. Ectomycorrhizal, arbuscular mycorrhizal (AM) and septate endophytic fungal associations in gymnosperms. a: Transverse section of Pinus roxburghii root showing mantle (mn) and fungal hyphae (fh); b: Hartig net (arrow heads) in root cortex of Pi. roxburghii; c: Hyphal coils (hc) in Platycladus orientalis; d: Arbusculate coil (ac), intracellular (ih) and intercellular (inh) hyphae in cortical cell of Podocarpus macrophyllus; e: Intra-cellular vesicle (v) in Cycas circinalis; f: Intercalary vesicle in Cupressus macrocarpa; $\mathbf{g}$ : Intracellular AM hyphal coil (hc) in Cryptomeria japonica; $\mathbf{h}$ : Septate hyphae (sh) in Cupressus torulosa. i: Septate hyphae (sh) in Cy. circinalis; j: AM fungal spores (sp) in root of Zamia furfuracea; $\mathbf{k}$ : microsclerotia (ms) in root cortical cell of Thuja sp. Scale bars=50 $\mu \mathrm{m}$. 


\begin{tabular}{|c|c|c|c|c|c|c|c|c|c|c|}
\hline \multirow[b]{2}{*}{$\begin{array}{l}\text { Family } \\
\text { Plant name }\end{array}$} & \multicolumn{7}{|c|}{ AM colonization $(\%)$} & \multicolumn{3}{|c|}{ SE colonization (\%) } \\
\hline & RLH & RLHC & RLAC & RLV & RLTC & $\begin{array}{l}\text { Spore } \\
\left(100 \mathrm{~g}^{-1}\right)\end{array}$ & SM & RLDH & RLMI & RLDTC \\
\hline \multicolumn{11}{|l|}{ Araucariaceae } \\
\hline $\begin{array}{l}\text { Araucaria } \\
\text { heterophylla }\end{array}$ & - & $26.61 \pm 1.71^{d}$ & $11.70 \pm 1.19$ & $5.19 \pm 1.72$ & $43.51 \pm 0.82$ & $25.33 \pm 2.60$ & CE, GV & - & $4.56 \pm 1.32$ & $4.56 \pm 1.32$ \\
\hline \multicolumn{11}{|l|}{ Cupressaceae } \\
\hline $\begin{array}{l}\text { Chamaecyparis } \\
\text { obtusa }\end{array}$ & - & $24.49 \pm 2.14$ & $14.20 \pm 1.34$ & $2.56 \pm 0.56$ & $41.25 \pm 2.60$ & $3.67 \pm 1.76$ & FG, GA & $7.75 \pm 1.17$ & $0.64 \pm 0.14$ & $8.39 \pm 0.71$ \\
\hline $\begin{array}{l}\text { Cupressus } \\
\text { macrocarpa }\end{array}$ & - & $42.44 \pm 3.84$ & $14.79 \pm 0.43$ & $3.55 \pm 0.08$ & $60.78 \pm 3.92$ & $6.67 \pm 1.76$ & GV, FM & - & - & - \\
\hline $\begin{array}{l}\text { Cupressus } \\
\text { sempervirens }\end{array}$ & - & $36.91 \pm 0.71$ & $17.90 \pm 2.84$ & $9.52 \pm 2.98$ & $64.34 \pm 3.29$ & $4.33 \pm 1.86$ & CE, SC & $2.96 \pm 0.58$ & $2.37 \pm 0.57$ & $5.33 \pm 1.06$ \\
\hline $\begin{array}{l}\text { Cupressus } \\
\text { torulosa }\end{array}$ & - & $33.79 \pm 0.87$ & $15.73 \pm 0.63$ & $11.89 \pm 0.95$ & $61.39 \pm 1.40$ & $37.67 \pm 2.91$ & CE, FG & $0.62 \pm 0.12$ & - & $0.62 \pm 0.12$ \\
\hline $\begin{array}{l}\text { Platycladus } \\
\text { orientalis }\end{array}$ & - & $27.70 \pm 2.06$ & $39.52 \pm 3.47$ & - & $67.23 \pm 4.09$ & $8.33 \pm 2.85$ & FG, CE & - & - & - \\
\hline Thuja sp. & $7.38 \pm 2.11$ & $24.42 \pm 0.87$ & $15.54 \pm 3.89$ & $3.01 \pm 1.68$ & $50.35 \pm 6.77$ & $13.67 \pm 2.40$ & CE, SC & $10.87 \pm 2.61$ & $5.84 \pm 1.12$ & $16.75 \pm 3.61$ \\
\hline \multicolumn{11}{|l|}{ Taxodiaceae } \\
\hline $\begin{array}{l}\text { Cryptomeria } \\
\text { japonica }\end{array}$ & - & $29.09 \pm 2.05$ & $12.97 \pm 1.05$ & - & $42.07 \pm 1.68$ & $14.33 \pm 1.88$ & FM, FG & - & - & - \\
\hline \multicolumn{11}{|l|}{ Cycadaceae } \\
\hline Cycas circinalis & $4.90 \pm 0.69$ & $22.02 \pm 2.53$ & $22.25 \pm 3.73$ & $14.24 \pm 1.57$ & $58.24 \pm 1.44$ & $15.33 \pm 2.40$ & FG & - & $0.74 \pm 0.25$ & $0.74 \pm 0.25$ \\
\hline \multicolumn{11}{|l|}{ Pinaceae } \\
\hline Pinus roxburghii & $4.05 \pm 0.20$ & $19.06 \pm 2.83$ & $32.65 \pm 4.01$ & - & $55.89 \pm 1.99$ & $3.67 \pm 0.67$ & FG, GA & - & - & - \\
\hline \multicolumn{11}{|c|}{ Podocarpaceae } \\
\hline Podocarpus sp. & $3.01 \pm 0.06$ & $13.27 \pm 2.46$ & $18.08 \pm 0.28$ & $14.45 \pm 1.79$ & $48.80 \pm 0.77$ & $13.00 \pm 2.65$ & $F G, F M$ & - & - & - \\
\hline $\begin{array}{l}\text { Podocarpus } \\
\text { elongata }\end{array}$ & - & $8.04 \pm 0.64$ & $38.97 \pm 3.94$ & $6.95 \pm 1.75$ & $54.13 \pm 5.12$ & $30.00 \pm 3.46$ & FG, CE & $3.75 \pm 1.07$ & - & $3.75 \pm 1.07$ \\
\hline $\begin{array}{l}\text { Podocarpus } \\
\text { macrophyllus }\end{array}$ & $13.98 \pm 1.52$ & $42.96 \pm 4.53$ & $14.11 \pm 2.66$ & $4.16 \pm 1.75$ & $61.23 \pm 0.47$ & $3.33 \pm 1.33$ & FM, SC & - & - & - \\
\hline $\begin{array}{l}\text { Prumnopitys } \\
\text { taxifolia }\end{array}$ & $3.97 \pm 0.40$ & $19.35 \pm 1.50$ & $23.92 \pm 1.08$ & $8.53 \pm 2.14$ & $58.10 \pm 4.29$ & $14.33 \pm 3.48$ & FG & - & - & - \\
\hline \multicolumn{11}{|l|}{ Zamiaceae } \\
\hline $\begin{array}{l}\text { Zamia } \\
\text { furfuracea }\end{array}$ & - & $31.45 \pm 0.36$ & $9.41 \pm 0.87$ & - & $41.52 \pm 1.63$ & $13.00 \pm 2.65$ & GV, SC & - & - & - \\
\hline
\end{tabular}

AM: Root length with hyphae (RLH), hyphal coils (RLHC), arbusculate coils (RLAC), vesicles (RLV) and AM total colonization (RLTC)

SE: Root length with dark septate hyphae (RLDH), microsclerotia (RLMI) and septate endophyte fungal total colonization (RLDTC)

Spore morphotype (SM): GV: Glomus viscosum; GA: Glomus aggregatum; CE: Claroideoglomus etunicatum; FM: Funneliformis mosseae; FG: Funneliformis geosporum; SC: Scutellospora calospora

Tabla 3. Extensión de la colonización por micorrizas arbusculares (M) y endófitos septados (SE) y número de esporas AM y diversidad asociada con gimnospermas del sur de la India. Los valores se expresan como media $\pm \mathrm{SE}$.

Table 3. Extent of arbuscular mycorrhizal (AM) and septate entophyte (SE) fungal colonization and AM fungal spore numbers and diversity associated with gymnosperms of southern India. The values are expressed as Mean $\pm \mathrm{SE}$.

Gerd) Walker \& Schüßler, Funneliformis mosseae (Nicolson \& Gerd) Walker \& Schüßler and Scutellospora calospora Walker \& Sanders. Spore numbers significantly varied among the plant species $\left(\mathrm{F}_{14,44}=16.88 ; \mathrm{P}<0.01\right)$. The AM fungal spore density ranged from 3 (Po. macrophyllus) to 38 (Cu. torulosa) spores per $100 \mathrm{~g}$ soil observed. $\mathrm{Fu}$. geosporum $(60 \%)$ was the most frequent species (Table 3; Fig. 3). The AM fungal spore numbers was not significantly related to $\%$ RLTC $(\mathrm{r}=-0.087, \mathrm{P}>0.05 ; \mathrm{n}=15)$.

\section{Occurrence of SE fungal association}

Septate endophytic fungal colonization characterized by the presence of darkly pigmented septate hyphae, microsclerotia and moniliform cells in root cortex was observed in six plant species. Typically melanized septate hyphae along with microsclerotia occurred in $33 \%$ of root samples examined (Table 3; Figs. 1h,1i, 1k). However, SE fungal structures were absent in eight plant species belonging to five families which included 


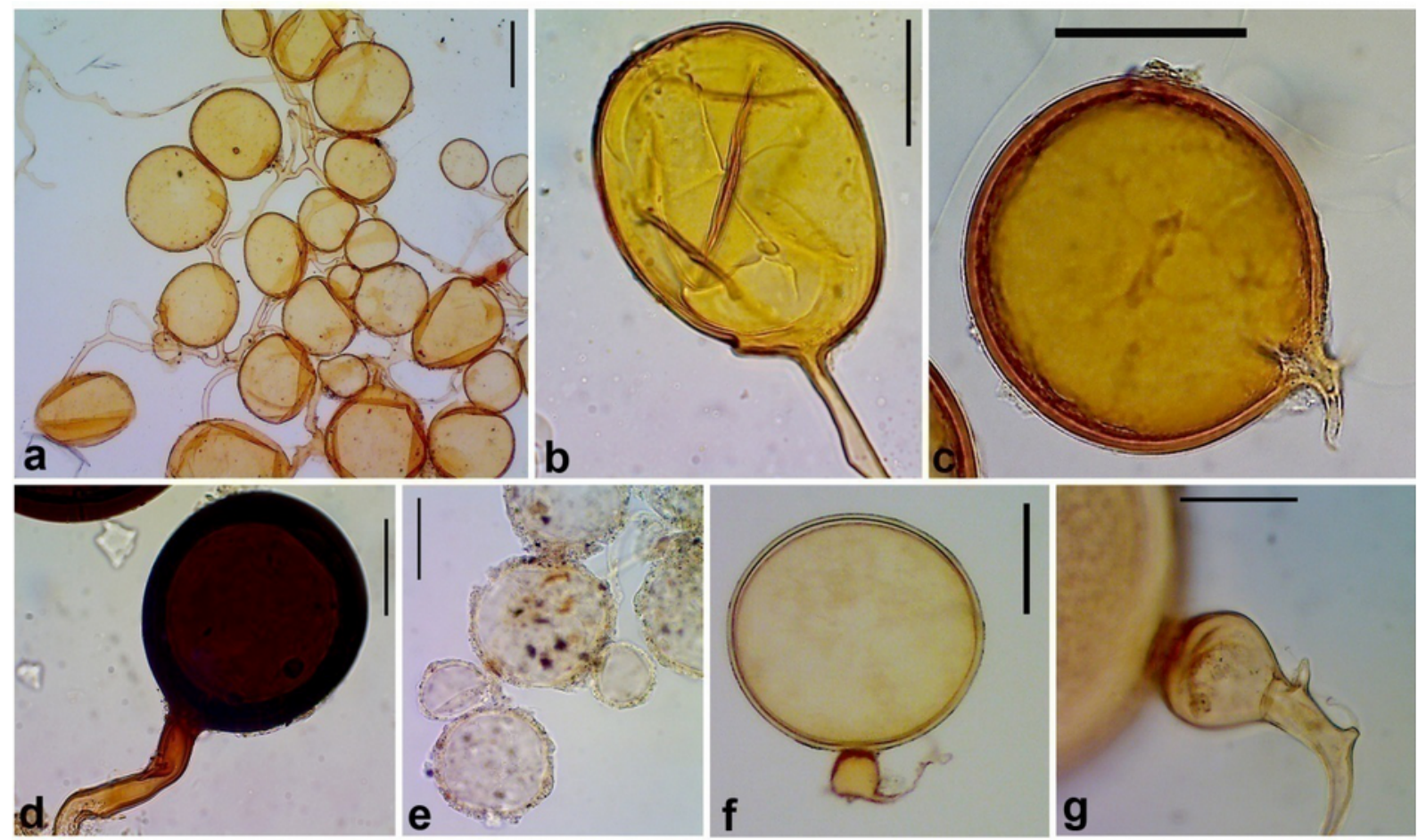

Figura 2. Esporas micorrícicas arbusculares asociadas a gimnospermas. a: Racimo de esporas de Glomus aggregatum; b: Espora de Gl. aggregatum; c: Espora de Claroideoglomus etunicatum; d: Espora de Funneliformis geosporum; e: Espora de Glomus viscosum; f: Espora de Scutellospora calospora; g: Hifa bulbosa subyacente de Sc. calospora. Barra de escala: a, $\mathrm{f}=100 \mu \mathrm{m} ; \mathrm{b}-\mathrm{e}, \mathrm{g}=50 \mu \mathrm{m}$.

Figure 2. Arbuscular mycorrhizal fungal spores associated with gymnosperms. a: Spore cluster of Glomus aggregatum; b: Single spore of Gl. aggregatum; c: Claroideoglomus etunicatum; d: Funneliformis geosporum; e: Glomus viscosum; f: Scutellospora calospora; g: bulbous subtending hyphae of $S$. calospora. Scale bars: a, $\mathrm{f}=100 \mu \mathrm{m} ; \mathrm{b}-\mathrm{e}, \mathrm{g}=50 \mu \mathrm{m}$.

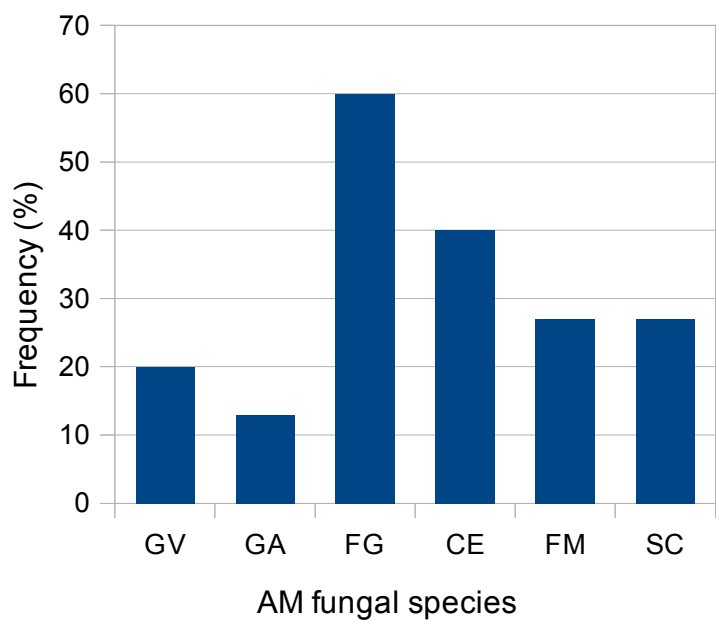

Figura 3. Frecuencia de morfotipos de esporas fúngicas en la zona de las raíces de las gimnospermas. GV: Glomus viscosum; GA: Glomus aggregatum; FG: Funneliformis geosporum; CE: Claroideoglomus etunicatum; FM: Funneliformis mosseae; SC: Scutellospora calospora.

Figure 3. Frequency of arbuscular mycorrhizal (AM) fungal spore morphotypes in the root zones of gymnosperms. GV: Glomus viscosum; GA: Glomus aggregatum; FG: Funneliformis geosporum; CE: Claroideoglomus etunicatum; FM: Funneliformis mosseae; SC: Scutellospora calospora.
Pl. orientalis, $\mathrm{Cu}$. macrocarpa, $\mathrm{Cr}$. japonica, $\mathrm{Pi}$. roxburghii, Podocarpus sp., Pr. taxifolia, Po. macrophyllus and Za. furfuracea.

\section{Extent of SE fungal colonization}

The percentage of root length colonized by SE fungal hyphae $(\% \mathrm{RLDH})$ ranged from $1 \%(\mathrm{Cu}$. torulosa) to $11 \%$ (Thuja sp.,). The percentage root length with microsclerotia (\%RLMI) ranged from $1 \%$ (Ch. obtusa, Cy. circinalis) to 6\% (Thuja sp.). The percentage root length with total SE colonization (\% RLDTC) ranged between $1 \%(\mathrm{Cu}$. torulosa, Cy. circinalis) and 17\% (Thuja sp.) (Table $3)$. The \% RLDTC and root length with SE fungal structures varied significantly $(\mathrm{P}<0.01)$ among plant species (\% RLDTC, $F_{14,44}=15.27$; \% RLDH, $\mathrm{F}_{14,44}=16.65 ; \%$ RLMI, $\mathrm{F}_{14,44}=8.09$ ) (Table 3). No significant correlation existed between \% RLDTC and $\%$ RLTC $(\mathrm{r}=-0.259, \mathrm{P}>0.05 ; \mathrm{n}=15)$.

\section{Discussion}

The high incidence of AM fungal colonization in gymnosperms in the present investigation is con- 
sistent with studies where a high incidence of AM was reported in gymnosperms (Muthukumar \& Udaiyan 2002, Yamato \& Iwasaki 2002, Muthukumar et al. 2006). Likewise, most of the vascular plants in a coniferous forest in New Zealand were also found to be colonized by typical mycorrhizal endophytes (Johnson 1977). The high prevalence of mycorrhizae in the gymnosperms observed could be attributed to the low levels of $P$ in tropical soils as evidenced in the present study. Generally, at low levels of available P in soils, most of the plant species, including gymnosperms are highly dependent on AM fungi to satisfy their nutrient demands (Moreira \& Cardoso 2002). This might be the reason for the high frequency of mycorrhizal association in gymnosperms in the present and other studies.

Previous information on mycorrhizal status of gymnosperms is available for only four of the 15 species examined in the present study. This clearly indicates the fact that only few gymnosperms from tropical regions have been examined for their mycorrhizal status despite the general assumption that mycorrhizal symbiosis is widespread among gymnosperms (Smith \& Smith 1997, Muthukumar \& Udaiyan 2000, Muthukumar et al. 2006, Bagyalakshmi et al. 2010). Frequent occurrence of mycorrhizae in gymnosperms, especially in members of Podocarpaceae has often been attributed to their high mycorrhizal dependency. For example, Baylis (1969) indicated that mycorrhizal association was essential to sustain growth and development of Podocarpus seedlings in natural soils. In addition to roots, root nodules of Podocarpus were shown to contain structures of AM fungi (Russell et al. 2002). However, we did not observe any AM fungal structures in the root nodules of any of the Podocarpus examined in the present study. Similarly, earlier authors have also reported the presence of AM fungal association in members of Araucaria like Ar. angustifolia (Milanez \& Monteiro 1950, Oliveira \& Ventura 1952, Bononi et al. 1989, Breuninger et al. 2000; Moreira et al. 2006).

Gymnosperms in the present study had a moderate level of AM colonization (54\%) which is in accordance with the findings of Muthukumar \& Udaiyan (2002) who also observed moderate levels $(45 \%)$ of AM fungal colonization in cycads of southern India. In contrast, Hurst et al. (2002) reported more intense AM fungal colonization (96\%) in Podocarpus species from New Zealand as against the present study. Generally, the intensity of AM colonization in plant roots is determined mainly by root traits like the root fineness and architecture (Baylis 1975). Nevertheless, Dickie \& Holdaway (2011) showed that podocarps with dense fine roots can be intensly colonized AM fungi. Reports on AM colonization patterns in gymnosperms are scarce and most of the studies examining the prevalence of mycorrhizae in gymnosperms have only reported the presence of AM symbiosis. To our knowledge, AM morphology has been reported in 11 gymnosperms for the first time. Predominance of Paris-type (9/15) AM morphology in the present study is similar to the observations of Yamato \& Iwasaki (2002) where Paris-type AM morphology was found to be common in gymnosperms examined from the broad leaved forests in Japan. Likewise, Paristype tends to occur more frequently than Arumtype in the plant families in mixed pine forest on a sand dune in central Honshu, Japan (Ahulu et al. 2005). Cr. japonica had Paris-type AM in the present study similar to the observations of Gallaud (1905) and Konoe (1957). Brundrett \& Kendrick (1990) and Imhof \& Weber (1997) suggested that Paris-type colonization could be more beneficial than Arum-type to plants with slowgrowing and longer lived roots, and especially for plants growing under the unfavorable shaded conditions of the forest ecosystem. Although some uncertainty exists over the function of hyphal coils, there is ample evidence to believe that hyphal coils do transfer $\mathrm{P}$ to plant root cells like arbuscules (Dickson et al. 2007). As mycoheterotrophic AM plants receiving organic carbon always form Paris-type AM, it has been suggested that plants with Paris-type AM morphology tend to acquire carbon in addition to nutrients via fungi (Dickson et al. 2007). Therefore, intracellular hyphal coils of Paris-type AM are considered to be more advanced compared to the intercellular linear hyphae of the Arum-type (Weber et al. 1995).

In the present study, Pi. roxburghii was EM at the site-A, and AM at site-B. Though members of the Pinaceae are EM (Brundrett 2009), certain species of this family-like Pinus ponderosa Douglas ex C.Lawson has been reported to be either AM or EM at different sites (Wang \& Qiu 2006). 
Wagg et al. (2008) reported the co-occurence of $\mathrm{AM}$ and EM fungi along with SE in seedlings of three Pinus species (Pi. banksiana, Pi. strobus, $P i$. contorta) in the disturbed forest site of central Canada. Nevertheless, we did not observe such multiple associations in any of root samples of $P i$. roxburghii examined.

Arbuscular mycorrhizal fungal spore diversity in tropical soils is usually dominated by Glomus sp., as observed in the present and other studies (Ragupathy \& Mahadevan 1993; Muthukumar et al. 2003; Sathiyadash et al. 2010). This could be an adaptive feature of Glomus to thrive in low fertile and highly stressed tropical soils (Muthukumar \& Udaiyan 2002). The presence of spores belonging to Scutellospora is often related to the soil texture, as sandy soils have been shown to harbour this large spored species. However, Muthukumar \& Udaiyan (2002) recorded an abundance of Glomus and Scutellospora in the rhizhosphere soil of cycads (Cy. circinalis, Cycas revoluta Thunb. and Zamia sp.). The low AM fungal spore density in the present study may be due to the high root density in the forest soil and the perennial nature of the host roots which may defer AM fungal sporulation (Uma et al. 2012). This is in accordance with the findings of Muthukumar et al. (2006) who also observed low spore numbers in the root zones of Cy. circinalis. A low AM spore density in the soil does not indicate the low abundance of AM fungal propagules in the soil as the extraradical hyphae and mycorrhizal roots may also act as propagules during mycorrhization (Smith \& Read 2008).

In our study, $47 \%$ of the gymnosperms were colonized by SE fungi. Of these, SE is reported for the first time in five gymnosperms. This is in line with the observations of Ahlich \& Sieber (1996) and Jumpponen \& Trappe (1998) who also reported SE fungal colonization in roots of conifers. Septate endophytes were also reported to be more common in coniferous boreal forests (Richard and Fortin 1974). A synthesis on the prevalence of SE fungal association in vascular plants by Jumpponen \& Trappe (1998) indicated that 31 gymnosperms belonging to Cupressaceae (6 species) and Pinaceae (25 species) to be colonized by SE fungi. Septate endophytes have been reported from various geographical areas and in association with a wide range of plant species (Jumpponen \& Trappe 1998), suggesting that SE could be as abundant as AM (Mandyam \& Jumpponen 2005). The dual colonization of AM and SE fungi and the lack of any relationship between these endophytes in the present study suggest that these fungal endophytes possibly occupy different niches within the same root system (Wagg et al. 2008). Microsclerotia formed by SE fungi are considered to be storage structures and usually contains polysaccharides, polyphosphorous and proteins as the main storage resources (Jumpponen \& Trappe 1998). However, Currah et al. (1993) suggested that root cells containing microsclerotia may also act as the source of SE fungal inoculum and the study by Yu et al. (2001) also strengthens this view. However, in the present study, the low intensity in the presence of microsclerotia ( $6 \%$ of the root length) may be due to insufficient nutrient allocation to the fungal symbiont as suggested by Wagg et al. (2008).

In conclusion, the present study showed the frequent occurrence of mycorrhizal associations in gymnosperms of southern India. As mycorrhizal association plays a vital role in the survival of gymnosperms especially during the early stages of its growth and also in disturbed sites, further studies in this field, would enlighten the ecological importance of different endophytic fungal associations in tropical gymnosperms.

\section{References}

Addy HD, Piercey MM \& Currah RS. 2005. Microfungal endophytes in roots. Canadian Journal of Botany 83: 1-13.

Ahlich K \& Sieber TN. 1996. The profusion of dark septate endophytic fungi in non-mycorrhizal fine roots of forest trees and shrubs. New Phytologist 132: 259-270.

Ahulu EM, Nakata M \& Nonaka M. 2005. Arum and Paristype of arbuscular mycorrhiza in a mixed pine forest on sand dune in Niigata Prefecture, central Honshu, Japan. Mycorrhiza 15: 129-136.

Allen EB, Allen MF, Helm DJ, Trappe JM, Molina R \& Rincon E. 1995. Patterns and regulation of mycorrhizal plant and fungal diversity. Plant and Soil 170: 47-62.

Bakshi BK. 1957. Occurrence of mycorrhiza on some Indian conifers. Mycologia 49: 269-272.

Bagyalakshmi G, Muthukumar T, Sathiyadash K \& Muniappan V. 2010. Mycorrhizal and dark septate fungal associations in shoal species of Western Ghats, southern India. Mycoscience 51: 44-52.

Baylis GTS. 1969. Mycorrhizal nodules and growth of Podocarpus in nitrogen-poor soil. Nature 223: 1385-1386.

Baylis GTS. 1975. The magnolioid mycorrhiza and mycotrophy in root systems derived from it. In: Endomycorrhizas (Sanders FE, Mosse B \& Tinker PB, eds.). Academic Press, NewYork. pp. 373-389 
Beena KR, Raviraja NS, Arun AD \& Sridhar KR. 2000. Diversity of arbuscular mycorrhizal fungi on coastal sand dunes of the West Coast of India. Current Science 79: 1459-1465.

Bever JD, Schultz PA, Pringle A \& Morton JB. 2001. Arbuscular fungi: more diverse than meets the eye and the ecological tale of why. BioScience 51: 923-932.

Bononi VLR, Grandi RAP, Lopes SAR, Rodrigues E \& Fonseca MP. 1989. Micorrizas vesiculo-arbusculares em Araucaria angustifolia (Bert.) O. Ktze. In: Reunião Brasileira Sobre Micorrizas, 3. Piracicaba, Livro de resumos.

Breuninger M, Einig W, Magel E, Cardoso E \& Hampp R. 2000. Mycorrhiza of Brasil pine (Araucaria angustifolia Bert. O. Ktze). Plant Biology 2: 4-10.

Brundrett M \& Kendrick B. 1990. The roots and mycorrhizas of herbaceous woodland plants. 1. Quantitative aspects of morphology. New Phytologist 114: 457-468.

Brundrett MC. 2009. Mycorrhizal associations and other means of nutrition of vascular plants: Understanding the global diversity of host plants by resolving conflicting information and developing reliable means of diagnosis. Plant and Soil 320: 37-77.

Brundrett MC, Bougher N, Dell B, Grove T \& Malajczuck N. 1996. Working with mycorrhizas in forestry and agriculture. ACIAR Monograph no: 32. ACIAR, Canberra.

Caravaca F, Barea JM, Palenzuela J, Figuerosa D, Alguacil MM \& Roldán A. 2003. Establishment of shrub species in a degraded semi arid site after inoculation with native or allochthonous arbuscular mycorrhizal fungi. Applied Soil Ecology 22:103-111.

Currah RS, Tsuneda A \& Murakami S. 1993. Morphology and ecology of Phialocephala fortinii in roots of Rhododendron brachycarpum. Canadian Journal of Botany 71: 1639-1644.

Diagne N, Diouf D, Svistoonoff S, Kane A, Noba K, Franche C, Bogusz D \& Duponnois R. 2013. Casuarina in Africa: Distribution, role and importance of arbuscular mycorrhizal, ectomycorrhizal fungi and Frankia on plant development. Journal of Environmental Management 128: 204209.

Dickie IA \& Holdaway RJ. 2011. Podocarp roots, mycorrhizas and nodules. In: Ecology of the Podocarpaceae in Tropical Forests Smithsonian Contribution to Botany, no.95. (Turner BC \& Cernusak LA, eds). Smithsonian Institution Scholarly Press, Washington DC. pp 175-187.

Dickson S. 2004. The Arum-Paris continuum of mycorrhizal symbioses. New Phytologist 163: 187-200.

Dickson S, Smith FA \& Smith SE. 2007. Structural differences in arbuscular mycorrhizal symbioses: more than 100 years after Gallaud, where next? Mycorrhiza 17: 375393.

Gallaud I. 1905. "Études sur les mycorrhizes endotrophes". Revue générale de Botanique 17: 5-48, 66-83, 123-135; 223-239; 313-325; 425-433; 479-500.

Ghildiyal SK, Sharma CM \& Gairola S. 2010. Variation in morphological characters of mycorrhizal seedlings of various provenances of Pinus roxburghii Sargent. New York Science Journal 3: 1-8.

Helgason T, Merryweather JW, Denison J, Wilson P, Young JPW \& Fitter AH. 2002. Selectivity and functional diversity in arbuscular mycorrhizas of co-occuring fungi and plants from a temperate deciduous woodland. Journal of Ecology 90: 371-384.

Horton TR, Cázares E \& Bruns TD. 1998. Ectomycorrhizal, vesicular-arbuscular and dark septate fungal colonization of bishop pine (Pinus muricata) seedlings in the first 5 months of growth after wildfire. Mycorrhiza 8: 11-18.

Hurst SE, Turnbull MH \& Norton DA. 2002. The effect of plant light environment on mycorrhizal colonisation in field-grown seedlings of podocarp-angiosperm forest tree species. New Zealand Journal of Botany 40: 65-72.

Imhof S. \& Weber HC. 1997. Root anatomy and mycotrophy (AM) of the achlorophyllous Voyria truncata (Standley) Standley and Steyermark (Gentianaceae). Acta Botanica 110: $127-134$

Iqbal SH, Shahbaz \& Nazim G. 1990. State of mycorrhizae in some ornamental gymnospermous tree species of Pakistan. Pakistan Journal of Forestry 40: 237-246.

Jackson ML. 1971. Soil Chemical Analysis. Prentice Hall, New Delhi.

Johnson NP. 1977. Mycorrhizal Endogonaceae in a New Zealand forest. New Phytologist 78: 161-170.

Jumpponen A \& Trappe JM. 1998. Dark septate endophytes: a review of facultative biotrophic root colonizing fungi. New Phytologist 140: 295-310.

Konoe R. 1957. Uber das Vorkommen der Wurzelpilzeber Metasequota und den nachst Verwantden in Pflanzen. Journal of the Institute of Polytechniques, Osaka City University 8: 179-184.

Koske RE \& Gemma JN. 1989. A modified procedure for staining roots to detect VA-mycorrhizas. Mycological Research 92: 486-488.

Mandyam K \& Jumpponen A. 2005. Seeking the elusive function of the root-colonising dark septate endophytic fungi. Studies in Mycology 53: 173-189.

McGonigle TP, Miller MH, Evans DG, Fairchild GL \& Swan JA. 1990. A new method which gives an objective measure of colonization of roots by vesicular-arbuscular mycorrhizal fungi. New Phytologist 115: 495-501.

Milanez FRK \& Monteiro H. 1950. Nota préviaso bremicorrizano pinho do Paraná. Arquivos do ServiçoFlorestal 4: 87-93.

Moreira M \& Cardoso EJBN. 2002. Dependência micorrízicade Araucaria angustifolia (Bert.) O. Ktze. sob doses de fósforo. Revista Brasileira de Ciência do Solo 26: 905-912

Moreira M, Trufem SFB, Gomes-Da-Costa SM \& Cardoso EJBN. 2003. Arbuscular mycorrhizal fungi associated with Araucaria angustifolia (Bert.) O. Ktze. Mycorrhiza 13: 211-215.

Moreira M, Baretta D, Tsai SM \& Cardoso EJBN. 2006. Spore density and root colonization by arbuscular mycorrhizal fungi in preserved or disturbed Araucaria angustifolia (Bert.) O. Ktze., ecosystems. Scientia Agricola (Piracicaba, Braz.) 63: 380-385.

Muthukumar T \& Udaiyan K. 2000. Arbuscular mycorrhizas of plants growing in the Western Ghats region, Southern India. Mycorrhiza 9: 297-313.

Muthukumar T \& Udaiyan, K. 2002. Arbuscular mycorrhizas in cycads of southern India. Mycorrhiza 12: 213-217.

Muthukumar T, Sha L, Yang X, Cao M, Tang J \& Zheng Z. 2003. Mycorrhiza of plants in different vegetation types in tropical ecosystems of Xishuangbanna, southwest 
China. Mycorrhiza 13:289-297.

Muthukumar T, Senthilkumar M, Rajangam M \& Udaiyan K. 2006. Arbuscular mycorrhizal morphology and dark septate fungal associations in medicinal and aromatic plants of Western Ghats, southern India. Mycorrhiza 17:11-24.

Oliveira M \& Ventura A. 1952. A ocorrência de micorrizaem Araucaria angustifolia (Bert.) O. Ktze e Podocarpus lamberti. SãoPaulo: Serviço Florestal 5: 25.

Ouahmane L, Hafidi M, Thioulouse J, Ducousso M, Kisa M, Prin Y, Galiana, A, Boumezzough A \& Dupponnois R. 2007. Improvement of Cupressus atlantica Gaussen growth by inoculation with native arbuscular mycorrhizal fungi. Journal of Applied Microbiology 103: 683-690.

Ragupathy S \& Mahadevan A. 1993. Distribution of vesicular arbuscular mycorrhizae in the plants and rhizosphere soil of the tropical plains, Tamil Nadu, India. Mycorrhiza 3: 123-136.

Rawat PS, Punj N \& Chand F. 2004. Seasonal distribution and infection intensity of ectomycorrhizae in Pinus roxburghii Forest. Indian Forester 130: 405-415.

Richard C \& Fortin J-A. 1974. Distribution, geographique, ecologie, physiologie, pathogenecite et sporulation du Mycelium radicis atrovirens. Phytoprotection 55: 67-88.

Russell AJ, Bidartondo MI \& Butterfield BG. 2002. The root nodules of the Podocarpaceae harbour arbuscular mycorrhizal fungi. New Phytologist 156: 283-295.

Sathiyadash K, Muthukumar T \& Uma E. 2010. Arbuscular mycorrhizal and dark septate fungal associations in South Indian grasses. Symbiosis 52: 21-32.

Schenck NC \& Perez Y. 1990. Manual for Identification of VA Mycorrhizal Fungi. INVAM, University of Florida, Gainesville.

Singer R \& Singh B. 1971. Two new ectotroph-forming boletes from India. Mycopathologia et Mycologia Ap- plicata 43: 25-33

Smith FA \& Smith SE. 1997. Structural diversity in vesiculararbuscular mycorrhizal symbioses. New Phytologist 137: 373-388.

Smith SE \& Read DJ. 2008. Mycorrhizal Symbiosis. Academic Press, New York.

Srivastava RC. 2006. Diversity and economical importance of living gymnosperms in India. National Academy Science Letters 29: 75-84.

St. John TV \& Koske RE. 1988. Statistical treatment of endogonaceous spore counts. Transactions of the British Mycological Society 91: 117-121.

The Plant List. 2015. Available at: http://www.theplantlist.org (accessed on 03/I/2015).

Uma E, Sathiyadash K, Loganathan J \& Muthukumar T. 2012. Tree species as hosts for arbuscular mycorrhizal and dark septate endophyte fungi. Journal of Forest Research 23: 641-649.

Wagg C, Pautler M, Massicotte HB \& Peterson RL. 2008. The co-occurrence of ectomycorrhizal, arbuscular mycorrhizal, and dark septate fungi in seedlings of four members of the Pinaceae. Mycorrhiza 18: 103-110.

Wang B \& Qiu YL. 2006. Phylogenetic distribution and evolution of mycorrhizas in land plants. Mycorrhiza 16: 299363.

Weber HC, Klahr A \& Manon-Heimbuch M. 1995. Anatomical structures of the VA mycorrhiza in the Apocynaceae (Gentianales). Botanica Acta 108: 525-534.

Yamato M \& Iwasaki M. 2002. Morphological types of arbuscular mycorrhizal fungi in roots of understorey plants in Japanese deciduous broad leaved forests. Mycorrhiza 12: 291-296.

Yu TE-C, Egger KN \& Peterson RL. 2001. Ectendomycorrhizal association-characteristics and functions. Mycorrhiza 11: 167-177. 